\title{
Vitamin D intake and status in immigrant and native Swedish women: a study at a primary health care centre located at $60^{\circ} \mathrm{N}$ in Sweden
}

\author{
Åsa Andersson ${ }^{*}$, Anne Björk², Per Kristiansson² and \\ Gunnar Johansson² \\ 'Gottsunda Primary Health Care Centre, Uppsala, Sweden; ²Department of Public Health and Caring Sciences, \\ Family Medicine and Preventive Medicine, Uppsala University, Uppsala, Sweden
}

Abstract

Background: Immigration to Sweden from lower latitude countries has increased in recent years. Studies in the general population in other Nordic countries have demonstrated that these groups are at risk of developing vitamin $\mathrm{D}$ deficiency, but studies in primary health care patients are rare.

Objectives: The aim of this study is to examine possible differences in plasma-25(OH)-vitamin D levels and intake of vitamin D between Swedish and immigrant female patients in a primary health care centre located at $60^{\circ} \mathrm{N}$, where half of the inhabitants have an immigrant background. Another objective was to estimate what foods contribute with most vitamin D.

Design: Thirty-one female patients from the Middle East and Africa and 30 from Sweden were recruited. $\mathrm{P}-25(\mathrm{OH}) \mathrm{D}$ was measured and intake of vitamin $\mathrm{D}$ was estimated with a modified food frequency questionnaire (FFQ).

Results: Vitamin D deficiency (plasma-25(OH)D $<25 \mathrm{nmol} / \mathrm{L})$ was common among immigrant women $(61 \%)$. One immigrant woman and half of the Swedish women had optimal levels (plasma-25(OH)D $>50 \mathrm{nmol} / \mathrm{L}$ ). There was a positive correlation between the intake of vitamin D from food and plasma-25(OH)D. Only three women, all Swedish, reached the recommended intake of vitamin D from food. The immigrant women had lower intake compared to Swedish women (median: $3.1 \mathrm{vs.} 5.1 \mu \mathrm{g} /$ day). The foods that contributed with most vitamin D were fatty fish, fortified milk and margarine. Immigrant women consumed less fortified milk and margarine but more meat. Irrespective of origin, patients with plasma- $25(\mathrm{OH}) \mathrm{D}<25 \mathrm{nmol} / \mathrm{L}$ consumed less margarine but more meat.

Conclusion: Vitamin D deficiency was common in the immigrant patients and their intake of vitamin D was lower. This highlights the need to target information about vitamin D to immigrant women in order to decrease the risk for vitamin D deficiency. The FFQ was well adapted to its purpose to estimate intake of vitamin D.

Keywords: immigrants; vitamin D deficiency; primary health care; food; nutrition requirements

Received: 5 April 2013; Revised: 5 April 20I3; Accepted: 23 April 2013; Published: 20 May 20I3

$\mathrm{R}$ ecent research has shown that vitamin D deficiency is more prevalent than previously assumed and seems to have a correlation with a range of diseases, such as musculoskeletal pain, diabetes, depression, coronary heart disease, cancer, psoriasis and multiple sclerosis (1-4). The discovery of the presence of vitamin $\mathrm{D}$ receptors in different tissues has also led to an increased interest in this vitamin.
Vitamin D is synthesized in the skin after sun exposure and can also be obtained through nutritional intake (2). Globally, the vitamin D synthesis in skin is most important, but in sun-deprived regions such as northern countries, the nutritional contribution is more important. The skin synthesizing process is dependent on the latitude, skin type, age, clothing, usage of sun screen and air pollution (5). People who spend little time outdoors and 
whose food has a low content of vitamin D are at risk of developing vitamin $\mathrm{D}$ deficiency.

In food, vitamin D exists in two different forms, ergocalciferol (vitamin $\mathrm{D}_{2}$ ) and cholecalciferol (vitamin $D_{3}$ ). From a nutritional point of view, the cholecalciferol form is most important and is found in fatty fish, egg yolks, meat products, poultry, as well as in fortified products, such as milk and margarine. The ergocalciferol form is found in some wild mushrooms (6).

Today, in Sweden, 15\% of the inhabitants were born in another country. The proportion originating from countries at lower latitudes (the Middle East and Africa) has grown. Another $4 \%$ have an immigrant background, meaning that they were born in Sweden but both their parents born in another country (7).

Studies on immigrants from lower latitudes $\left(7^{\circ}-40^{\circ} \mathrm{N}\right)$ living in Denmark and Norway have demonstrated a high prevalence of vitamin D deficiency, with the lowest levels in women (8-10). To date, there are few studies of vitamin D status among immigrant groups in Sweden and studies from primary health care patients in Nordic countries are rare $(11,12)$. Sääf et al. recently studied pregnant women originating from Somalia and showed extremely low levels of plasma 25-hydroxyvitamin D, or 25(OH)D.

Thus, it is of great importance to further examine vitamin D status and the intake of vitamin D among immigrant groups in Sweden.

Vitamin D status is most often determined by measuring 25-hydroxyvitamin D 25(OH)D in serum or plasma. This form of the vitamin is considered to best reflect the body supply (13). A value for $25(\mathrm{OH}) \mathrm{D}$ above $50 \mathrm{nmol} / \mathrm{L}$ has been regarded as a safe lower reference limit and values $<25 \mathrm{nmol} / \mathrm{L}$ as deficient (14).

The aim of this study is to determine whether there are differences in plasma-25(OH)D levels and intake of vitamin D between immigrant and Swedish women attending a primary care health centre in Uppsala and to examine what kind of foods contributed most vitamin D.

\section{Subjects and methods}

This study was performed in a district in Uppsala where half the inhabitants have immigrant backgrounds, with two-thirds of them originating from the Middle East (15). The study was carried out in co-operation between a dietician and a general practitioner. Inclusion criteria were female patients born in the Middle East or Africa aged 18-75. Exclusion criteria were on-going treatment for vitamin $\mathrm{D}$ deficiency and current pregnancy. Immigrant women attending the primary health care centre were consecutively, irrespective of reason for the appointment, asked if they would be willing to participate in a study concerning vitamin D. Those who were interested in participating received both oral and written information and signed a written consent form. A reference group consisting of 30 women born in Sweden was recruited in the same way at the centre. Four of the patients who were invited to participate chose not to participate, owing to lack of time and interest.

In the group of immigrant women, 31 women chose to participate. They originated from Iraq $(8-7$ of them from Kurdistan), Turkey (4), Palestine (4), Somalia (4), Iran (3), Syria (3), Eritrea (2), Jordan (1), Bangladesh (1) and Armenia (1). The immigrant women had lived in Sweden between 2 and 26 years, with a median time of 12 years.

The inclusion period was from January to March 2009. The women consulted the general practitioner and the dietician during the same appointment but separately from the recruiting appointment. Professional interpreter was used in six cases, and in one case, the husband was present and translated when needed. The general practitioner collected information on general health, medication, smoking, muscle pain, sun habits and reactions to sun exposure, education and, for the immigrants, how many years they had lived in Sweden. Most of these data will be reported elsewhere.

To estimate the intake of vitamin D from food, a semiquantitative food frequency questionnaire (FFQ) specially designed for this study was used (Appendix) The FFQ was designed by a dietician with good knowledge and experience on food habits in the studied ethnic groups. It consisted of 15 foods and 8 frequencies and aimed at estimating intake during the last 2 to 3 months. The FFQ included foods containing vitamin $\mathrm{D}_{3}$ naturally, foods fortified with vitamin $\mathrm{D}_{3}$ and corresponding foods not fortified, such as full fat milk. The FFQ also included vitamin supplements (brand and contents). The women were asked about the size of portions, numbers of glasses of milk, tablespoons of margarine and numbers of eggs. We carefully asked about which brands of milk and yoghurt they had consumed, and from the respective tables of contents, the amount of vitamin D was estimated. Concerning meat and fish, we assumed a main course to be $125 \mathrm{~g}$, which is a normal serving in Sweden. We did not use pictures of reference portions. If a woman mentioned that she consumed extra large or extra small sizes of portions, the frequency in the FFQ was changed accordingly. Since the vitamin D content in fatty fish is much higher than in lake lean fish, only fatty fish was included. The feasibility of the FFQ was checked with the patients, and all items in the FFQ were discussed together with each participant during the appointment. The interviews lasted 30-60 minutes. The Swedish national food agency database was used for the calculations of vitamin D intake (16).

Plasma levels of $25(\mathrm{OH}) \mathrm{D}$ were measured as well as plasma calcium. Plasma-25(OH)D was analyzed using an automatized immunochemical method (LIAISON ${ }^{\circledR}$ (Diasorin)) at the clinical chemistry laboratory, University Hospital in Uppsala. This laboratory takes part in the DEQAS quality programme since many years. According 
to the laboratory, their method gives accurate values and usually lies within $\pm 10 \%$ from the mean value in DEQAS. Height and weight were measured and body mass index (BMI) calculated. Vitamin D deficiency was defined as plasma-25(OH)D below $25 \mathrm{nmol} / \mathrm{L}$, insufficiency 25-50 $\mathrm{nmol} / \mathrm{L}$ and optimal levels $>50 \mathrm{nmol} / \mathrm{L}$. The participants were informed about the test results and they received oral and written advice about foods rich in vitamin D. Patients who were vitamin D deficient received supplements of calcium and vitamin $\mathrm{D}$, but that is not further discussed in this paper.

\section{Statistics}

An estimation of power carried out before the study, assuming $60 \%$ of vitamin D deficiency in the immigrant group and $20 \%$ in the Swedish group, indicated that samples from 60 women would be sufficient to reveal a statistically significant difference with $90 \%$ power using a two-sided test of significance and $p<0.05$. Data were analyzed with the SPSS (version 20.0) statistical programme packages. Neither the original data nor the log-transformed were normally distributed. Summary statistics such as medians, percentiles, and proportions were therefore computed using standard non-parametric methods. Differences in proportions were calculated with the chi-square test. Linear regression was used to evaluate the relationship between quantitative parameters. $p$ Values $<0.05$ were considered as statistical significance.

The study was approved by the local ethics committee at Uppsala University (Local ID number: 2008:359).

\section{Results}

Characteristics of the women by ethnic origin are shown in Table 1. The immigrant women were somewhat younger and had a significantly lower intake of vitamin D from food as well as total intake (from food and supplements), lower education (two of the immigrants had never been to school) and lower plasma-25(OH)D. One third of the immigrant women group were veiled. One of the Swedish women was converted into Islam and wore a burqa. Deficiency levels were common in the immigrant women but uncommon in Swedish women. Overall, optimal levels were rare among the immigrants.

Only three women (Swedish), reached the recommended daily intake for age from food (Fig. 1). Eleven women, two of them immigrant women, took supplements containing vitamin $\mathrm{D}_{3}$. Eight Swedish women and two immigrant women reached the recommended level of vitamin D intake when total intake of food and supplements was estimated. One immigrant woman had a high level of plasma-25(OH)D and she had received an injection of vitamin D due to pain while in Iran.

There was a positive correlation in the whole group between intake of vitamin $\mathrm{D}$ from food and plasma$25(\mathrm{OH}) \mathrm{D}$ (Fig. 2). We calculated the intake of vitamin D
Table 1. Demographics of the study population

\begin{tabular}{|c|c|c|c|}
\hline & $\begin{array}{l}\text { Immigrant } \\
\text { women }\end{array}$ & $\begin{array}{l}\text { Swedish } \\
\text { women }\end{array}$ & $P$ \\
\hline Number & 31 & 30 & \\
\hline Age (years) & 35 (29-49) & $42(30-57)$ & 0.19 \\
\hline BMI $\left(\mathrm{kg} / \mathrm{m}^{2}\right)$ & $28(24-32)$ & $26(2 I-32)$ & 0.36 \\
\hline Veiled & 10 & 1 & 0.006 \\
\hline Education & & & 0.001 \\
\hline School $<10$ years & 13 & I & \\
\hline School 10-12 years & 3 & 7 & \\
\hline School $>12$ years & 15 & 22 & \\
\hline Muscle pain (n) & & & 0.086 \\
\hline $\begin{array}{l}25(\mathrm{OH}) \mathrm{D} \\
<25 \mathrm{nmol} / \mathrm{L}\end{array}$ & 16 & 2 & \\
\hline $\begin{array}{l}\text { 25(OH)D } \\
\geq 25 \mathrm{nmol} / \mathrm{L}\end{array}$ & 11 & 15 & \\
\hline $\begin{array}{l}\text { P-25(OH)-vitamin D } \\
\quad(\mathrm{nmol} / \mathrm{L})\end{array}$ & $22.2(13.7-28.6)$ & $51.5(39.6-66.5)$ & $<0.001$ \\
\hline$<25 \mathrm{nmol} / \mathrm{L}$ & 19 & 2 & $<0.001$ \\
\hline $25-50 \mathrm{nmol} / \mathrm{L}$ & II & 12 & \\
\hline$>50 \mathrm{nmol} / \mathrm{L}$ & I & 16 & \\
\hline $\begin{array}{l}\text { Intake vitamin D } \\
\text { (food) ( } \mu \text { g/day) }\end{array}$ & $3.1(2.0-4.4)$ & $5.1(3.7-6.4)$ & \\
\hline $\begin{array}{l}\text { Intake vitamin D } \\
\text { (food + suppl.) } \\
(\mu g / \text { day })\end{array}$ & $3.1(2.0-4.7)$ & $5.8(4.0-9.0)$ & $<0.001$ \\
\hline P-calcium & $2.3(2.3-2.4)$ & $2.3(2.3-2.4)$ & 0.55 \\
\hline
\end{tabular}

Median (25-75th percentiles) and numbers are presented.

from different foods and those with a considerable amount are included in Tables 2 and 3. The immigrant and Swedish women obtained their vitamin D from food from different sources (Table 2). The immigrant women had a lower estimated intake of vitamin D from fortified milk and margarine on bread and in cooking than the

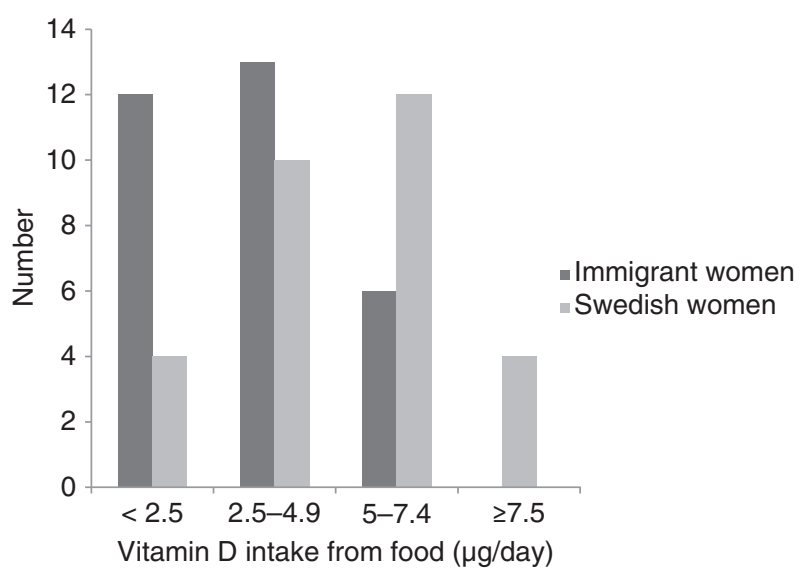

Fig. 1. Intake of vitamin D ( $\mu \mathrm{g} /$ day) from food in immigrant and Swedish women. 


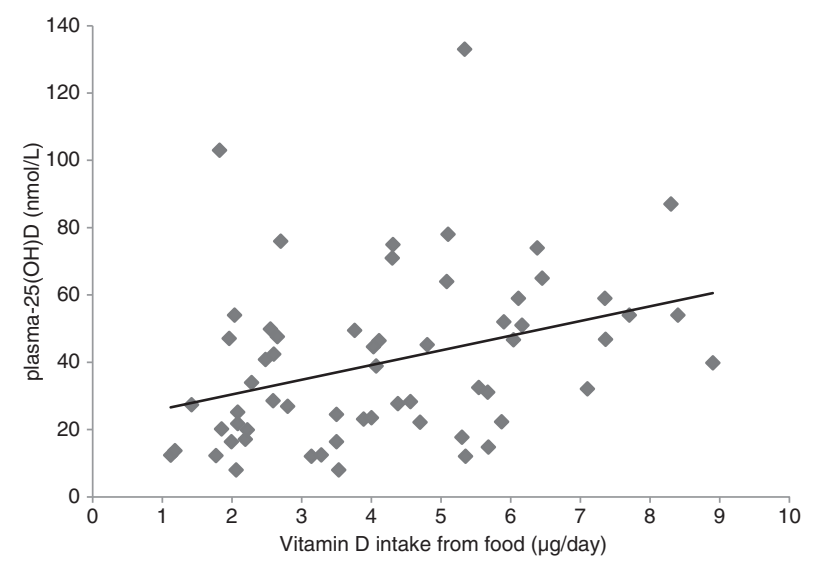

Fig. 2. Correlation between vitamin D intake from food and plasma $25(\mathrm{OH}) \mathrm{D}(\mathrm{nmol} / \mathrm{L})$ in all women. $r=0.35, p=0.006$.

Swedish reference group. The immigrant women had higher intake of vitamin D from lamb and chicken and the Swedish reference group obtained more vitamin D from pork and ham. The contribution of vitamin D from fatty fish and eggs was similar in the groups.

Women with plasma-25(OH)D $\geq 25 \mathrm{nmol} / \mathrm{L}$ had a higher intake of vitamin D from fortified milk, fortified margarine on bread and in cooking and pork than women with plasma-25(OH)D $<25 \mathrm{nmol} / \mathrm{L}$ (Table 3 ). The women with plasma-25(OH)D $<25 \mathrm{nmol} / \mathrm{L}$ consumed more lamb, and most of these women were immigrants.

Women with less than 10 years in school had lower plasma-25(OH)D than those with more than 10 years in school (median 19 vs. $45 \mathrm{nmol} / \mathrm{L}, p=0.003$ ).

Women who were vitamin D deficient had higher BMI and were younger than women with plasma-25(OH)D $\geq 25 \mathrm{nmol} / \mathrm{L}$. There was a negative correlation between BMI and plasma-25(OH)D in both groups (Fig. 3).

The immigrant women preferred to stay in the shade, while the Swedish reference group chose both sun and shade. There was no difference between plasma-25(OH)D

Table 2. Estimated intake of vitamin D ( $\mu \mathrm{g} /$ day) from different foods containing considerable amounts of vitamin D in immigrant women $(n=31)$ and Swedish women $(n=30)$

\begin{tabular}{llll}
\hline & \multicolumn{1}{c}{$\begin{array}{c}\text { Immigrant } \\
\text { women }\end{array}$} & Swedish women & $P$ \\
\hline Fatty fish & $\mathrm{I} .4 \mathrm{I}(0.94-2.02)$ & $\mathrm{I} .7 \mathrm{I}(0.47-2.7)$ & 0.454 \\
Margarine total & $0.26(0.02-0.7 \mathrm{I})$ & $\mathrm{I} .28(\mathrm{I} .25-2.19)$ & $0.0 \mathrm{II}$ \\
Fortified low-fat milk & $0.05(0-0.25)$ & $0.25(0.08-0.76)$ & 0.040 \\
Fortified low-fat yoghurt/ & $0(0-0.08)$ & $0(0-0.25)$ & 0.273 \\
$\quad$ sour milk & & & \\
Eggs & $0.12(0.03-0.28)$ & $0.12(0.08-028)$ & 0.504 \\
Meat, total intake & $0.43(0.33-0.58)$ & $0.30(0.26-0.5 \mathrm{I})$ & 0.029 \\
\hline
\end{tabular}

Median (25-75th percentiles).
Table 3. Estimated intake of vitamin D ( $\mu \mathrm{g} / \mathrm{day})$ from different foods containing considerable amounts of vitamin $\mathrm{D}$ in women with plasma-25(OH)D $<25 \mathrm{nmol} / \mathrm{L}(n=21)$ and $\geq 25 \mathrm{nmol} / \mathrm{L}(n=40)$ respective

\begin{tabular}{llll}
\hline & \multicolumn{1}{c}{$<25 \mathrm{nmol} / \mathrm{L}$} & \multicolumn{1}{c}{$\geq 25 \mathrm{nmol} / \mathrm{L}$} & \multicolumn{1}{c}{$P$} \\
\hline Fatty fish & $\mathrm{I} .4 \mathrm{I}(0.94-2.02)$ & $\mathrm{I} .4 \mathrm{I}(0.47-2.02)$ & 0.763 \\
Margarine, total & $0.217(0.02-\mathrm{I} .25)$ & $\mathrm{I} .25(0.52-1.75)$ & $0.00 \mathrm{I}$ \\
Fortified low-fat milk & $0.05(0-0.25)$ & $0.25(0-0.76)$ & 0.038 \\
Fortified low-fat yoghurt/ & $0(0-0.0 \mathrm{I})$ & $0(0-0.25)$ & 0.058 \\
$\quad$ & & & \\
$\quad$ sour milk & $0.12(0.03-0.28)$ & $0.12(0.08-0.28)$ & 0.487 \\
Meat, total intake & $0.49(0.38-0.58)$ & $0.34(0.27-0.50)$ & $0.02 \mathrm{I}$ \\
\hline
\end{tabular}

Median (25-75th percentiles).

in veiled and non-veiled immigrant women (data not shown).

There was no correlation between years in Sweden and vitamin D status. All women had normal levels of plasma calcium.

\section{Discussion}

We found that in our primary care patients, vitamin $\mathrm{D}$ deficiency, defined as plasma-25(OH)D $<25 \mathrm{nmol} / \mathrm{L}$, was more common in immigrant women than in Swedish women. However, even though few Swedish women were deficient, many of them had insufficient concentrations of vitamin $\mathrm{D}$. There was a significant correlation between vitamin $\mathrm{D}$ intake and plasma-25(OH)D. Immigrant women had lower intake of vitamin D from food and supplements. The main differences in intake of vitamin D from food were that the Swedish women consumed more fortified margarine on bread and in cooking and fortified milk. The other main contributor of vitamin D in food, fatty fish, was consumed in equal amounts in both groups.

Since 1980, the immigration to Sweden from the Middle East and Africa has increased. Within the

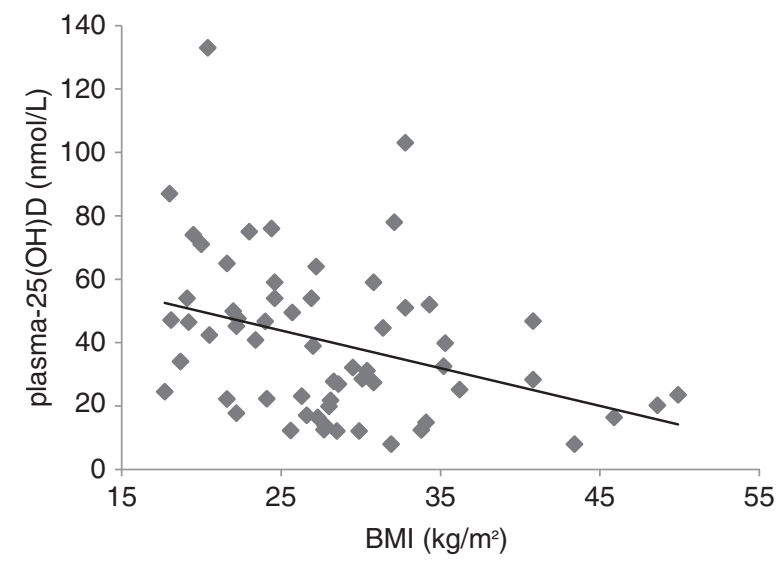

Fig. 3. Correlation between BMI $\left(\mathrm{kg} / \mathrm{m}^{2}\right)$ and plasma $25(\mathrm{OH}) \mathrm{D}(\mathrm{nmol} / \mathrm{L})$ in all women. $r=0.36, p=0.005$. 
catchment area of our primary care health centre, half of the population have immigrant backgrounds and of these, two-thirds originate from Middle Eastern countries. Our study population reflects this distribution well. To judge on the basis of clothing habits, skin type and food habits, many of them are at risk of low levels of vitamin D. Immigrants usually maintain most of their traditional food habits in the new country (17). Most of these foods are low in vitamin D. The results from our study show that the immigrant women consumed less margarine on bread and in cooking, presumably because these foods are not common to their traditional food habits.

Fortification of milk, milk products and margarine is one way of increasing intake of vitamin $\mathrm{D}$ and has proved to be a strategy to prevent vitamin D deficiency (18). In Sweden and Canada fortification of milk products is compulsory, while it is allowed but not compulsory in other countries (18-21). Present amounts of vitamin D fortification in Sweden are quite low: $0.38 \mu \mathrm{g} / 100 \mathrm{~g}$ in low-fat milk and low-fat milk products, $7.5-10 \mu \mathrm{g} / 100 \mathrm{~g}$ margarine and low-fat margarine. Different amounts of fortification in different countries imply difficulties when comparing intake of vitamin D.

Recommended daily intake of vitamin D in Sweden is $10 \mu \mathrm{g}$ for children aged $0-2,7.5 \mu \mathrm{g}$ for people aged 2-60 and $10 \mu \mathrm{g}$ for people aged $>60$. Assessment of food intake in Sweden, in a study in which people of age 18-74 years filled in a pre-coded 7-day record book, showed low intakes (average intakes were in the range of 4-6 $\mu \mathrm{g} /$ day) of vitamin $\mathrm{D}$ in all ages and for women $4.9 \mu \mathrm{g} /$ day (22). A new recent national survey (Riksmaten 2010-2011) demonstrated somewhat higher figures for Swedish women, but the response rate was very low (36\%) (23). In our study, when using our FFQ, the Swedish women had similar intake as measured in the first survey, while the immigrants had even lower intake of vitamin D.

The United States and Canada recently increased their recommended daily intake of vitamin $\mathrm{D}$, according to a report from the US Institute of Medicine (1). Finland has recently increased their recommended daily intake and prolonged supplementation to children with $7.5 \mu \mathrm{g}$ vitamin D up to 18 years of age (24). Raising recommendations of daily intake of vitamin $\mathrm{D}$ may be important but it is most probably unrealistic to reach these levels by changing food habits. Increased fortification of foods and/ or supplementation may also be necessary.

Another way to increase the daily intake of vitamin D in the population is to recommend prescribed or over the counter (OTC) supplements. The availability of OTC supplements has increased in Sweden during the last years. The dose that has been considered safe for longterm use is $50 \mu \mathrm{g} / \mathrm{day}$ for adults and $25 \mu \mathrm{g} /$ day for children (25). In 2010, the Institute of Medicine (IOM) raised the upper limit of tolerable intake to $100 \mu \mathrm{g} /$ day for adults (1).
Using an FFQ to estimate vitamin D intake was appropriate in this study. Our FFQ is short and less time-consuming than other methods. It is easy to use for patients whose language skills vary, especially since we discussed each item with the patients. Since some of the women in this study were illiterate, food records were not a possibility. Twenty-four-hour-recall is another option, but in the case of measuring vitamin $\mathrm{D}$ it is not a practical alternative since the vitamin exists in high levels in some foods people usually do not consume daily (26). The specially designed FFQ including only foods with relatively high vitamin $\mathrm{D}$ content saved time for the respondents and the staff. Baer et al. have shown that FFQ is a useful tool in classifying low-income pregnant American Indian and Caucasian women according to relative dietary intake, and can provide better assessments of usual intake over longer periods of time, such as weeks or months, rather than a single day (27). Taylor et al. showed that data derived from FFQ agree well with those from food record concerning vitamin D (28). They proposed that their FFQ can be effectively used to assess daily intake of calcium and vitamin D. Less robust correlations were observed for calcium intake. Snellman also used a self-administered FFQ consisting of 67 food items to estimate intake of vitamin D in her study of middle-aged and elderly women (29). The difference between our FFQ and the FFQs used by Baer and Taylor was that it was designed to estimate only vitamin $\mathrm{D}$, while they used more items, as they aimed to estimate other nutrients as well. Another difference was that we discussed each item with the patients, while their FFQs were self-administered.

Studies on the general population in Norway, Denmark and Finland have shown low concentrations of serum 25(OH)D for immigrant women from several Asian and African countries $(9,10,30)$. Women with higher education in the Norwegian study had higher concentrations of $25(\mathrm{OH}) \mathrm{D}$. This is in accordance with our results, showing higher levels of plasma-25(OH)D in women with $>10$ years education than in women with $<10$ years. In the Norwegian study, one in four women reported taking vitamin D supplements. In our study, only $7 \%$ of the immigrant women reported supplement intake. In Norway, vitamin D supplement with cod liver oil containing $10 \mu \mathrm{g}$ vitamin $\mathrm{D} / 5 \mathrm{~mL}$, is common among ethnic Norwegians, which probably also increases the awareness of the importance of vitamin D.

According to the American Institute of Medicine, blood levels of $50 \mathrm{nmol} / \mathrm{L}$ are needed for good bone health for practically all individuals. Other experts suggest a level of $75 \mathrm{nmol} / \mathrm{L}$ (31). In the recent years, tests for vitamin D have become more widely used, and confusion has increased about how much vitamin D is necessary. Furthermore, the measurements, or cut-off points, for sufficiency and deficiency used by laboratories to report results have not been set based on rigorous scientific 
studies, and no central authority has determined which cut-off points to use. A single individual may be deemed deficient or sufficient, depending on the laboratory where the blood is tested (1).

Can genetic factors be important for different metabolisms in people originating from different parts of the world? Physiological differences regarding bone health (e.g. gut resistance to actions of $1,25(\mathrm{OH})_{2} \mathrm{D}$ and differences in bone turnover) have been reported in African Americans as compared with whites (32). If vitamin D-deficient immigrants from Africa and the Middle East are not protected from skeletal loss owing to some ethnic/racial differences, major health problems could arise in the coming decades (9).

In our study, there was a strong negative correlation between BMI and plasma-25(OH)D. This is in accordance with other studies (33). Studies of women immigrants from Iran and Turkey have shown that the immigrant women had higher BMI and higher degrees of abdominal obesity than Swedish women (34, 35). It may be especially important to consider vitamin D-status when dealing with obese immigrant women from geographical areas such as the Middle East and Africa (36).

In sun-deprived areas such as Sweden, content of vitamin $\mathrm{D}$ in food is important to vitamin $\mathrm{D}$ status. At latitude $60^{\circ} \mathrm{N}$ (where Uppsala is situated) cutaneous synthesis of vitamin D is not detectable during the winter season (37). Clothing habits are important and a Norwegian study of vitamin D status in immigrants showed lower levels in veiled women (8). This is in accordance with our findings, although we found plasma-25(OH)D levels $<10 \mathrm{nmol} / \mathrm{L}$ even in non-veiled women.

One advantage of our study is that we included illiterate women, which was possible as we discussed each item in the FFQ with the patients personally. Illiterate patients are seldom included in studies, because of difficulties with language barriers and the need for interpreters. In spite of the fact that our study is relatively small, it included more patients than earlier Swedish studies investigating vitamin D in immigrant women (12). Another strength was that the dietician had great knowledge of food habits in the studied, ethnic groups, and that the FFQ was constructed from this knowledge and from foods that are available in Sweden.

One possible limitation of the FFQ is that it does not include some foods containing small amounts of vitamin $\mathrm{D}$, for example cakes, biscuits, pancakes, sauces and some lean lake fish. The semiquantitative design of the FFQ might have caused under- or overestimation of the vitamin D intake depending on the sizes of portions. However, studies have shown that extra questions concerning portion sizes are of little importance (38-40). Previous studies have shown great difficulties in measuring food habits in groups with different ethnic backgrounds. There is a need to develop methods with good validity (34). Although we used an interpreter, there was confusion with language in some cases. This might have had an impact on our results.

Another possible limitation of this study may be the choice of method for analyzing plasma-25(OH)D. Many assays for analyzing 25-hydroxyvitamin D are available, and their comparability is uncertain. HPLC (High-pressure liquid chromatography) is sometimes mentioned as a superior method for analyzing vitamin D $(41,42)$. The methods may differ in the case of vitamin $\mathrm{D}_{2}$ or $\mathrm{D}_{3}$, which is usually not of interest for monitoring vitamin D status. In our study, we found that two-thirds of the immigrants had deficient levels of plasma-25(OH)D $(<25 \mathrm{nmol} / \mathrm{L})$, but if we had used another method, for example, HPLC, probably fewer women would have had deficient levels. However, the difference in plasma-25(OH)D between our two groups would still remain.

The results from this study highlight the need to target information about vitamin $\mathrm{D}$ to immigrant women, independent of veil or skin pigmentation, and to detect vitamin $\mathrm{D}$ deficiency. Advice about choosing fortified foods and in some cases taking supplements should be considered. Extended education about the importance of vitamin $\mathrm{D}$ to midwives and nurses working in child health care could also prevent vitamin D deficiency in future generations. Another option is to increase fortification levels. However, since the immigrant women used less fortified foods, this would require, in the first place, that the foods would be purchased and consumed by those who need them. Another important aspect is to consider a possible correlation between vitamin D status and symptoms attributable to lack of vitamin $\mathrm{D}$.

\section{Acknowledgements}

Special thanks to the participating women and also to Wulf Becker for his help and valuable comments.

\section{Conflict of interest and funding}

None of the authors had any conflict of interest. The work was supported by the Department of Development and Research, Uppsala Primary Health Care and the Count Council of Uppsala.

\section{Contributions of authors}

$\AA \mathrm{A}, \mathrm{AB}$ and GJ initially planned the study. $\AA \mathrm{A}$ and $\mathrm{AB}$ carried out the data collections. All authors made substantial contribution to the statisitcal analyses, drafting of the manuscript, and revising it critically. All authors have read the and approved the final manuscript. 


\section{References}

1. IOM. IOM report on calcium and vitamin D. Washington, DC: Institute of Medicine; 2010. http://www.iom.edu/Reports/2010/ Dietary-Reference-Intakes-for-Calcium-and-Vitamin-D/DRIValues.aspx

2. Holick MF. Vitamin D deficiency. New Engl J Med 2007; 357: 266-81.

3. Zittermann A, Schleithoff SS, Koerfer R. Putting cardiovascular disease and vitamin D insufficiency into perspective. Br J Nutr 2005; 94: 483-92.

4. Vacek JL, Vanga SR, Good M, Lai SM, Lakkireddy D, Howard PA. Vitamin D deficiency and supplementation and relation to cardiovascular health. Am J Cardiol 2012; 109: $359-63$.

5. Burgaz A, Akesson A, Oster A, Michaelsson K, Wolk A. Associations of diet, supplement use, and ultraviolet B radiation exposure with vitamin D status in Swedish women during winter. Am J Clin Nutr 2007; 86: 1399-404.

6. Pearce SH, Cheetham TD. Diagnosis and management of vitamin D deficiency. BMJ 2010; 340: b5664.

7. SCB. http://www.scb.se/Pages/PressRelease_284708.aspx. 2009.

8. Holvik K, Meyer HE, Haug E, Brunvand L. Prevalence and predictors of vitamin D deficiency in five immigrant groups living in Oslo, Norway: the Oslo Immigrant Health Study. Eur J Clin Nutr 2005; 59: 57-63.

9. Andersen R, Molgaard C, Skovgaard LT, Brot C, Cashman KD, Jakobsen $\mathrm{J}$, et al. Pakistani immigrant children and adults in Denmark have severely low vitamin D status. Eur J Clin Nutr 2008; 62: 625-34.

10. Madar AA, Stene LC, Meyer HE. Vitamin D status among immigrant mothers from Pakistan, Turkey and Somalia and their infants attending child health clinics in Norway. Br J Nutr 2009; 1: 1052-8.

11. Sääf M, Fernell E, Kristiansson F, Barnevik Olsson M, Gustafsson SA, Bagenholm G. Severe vitamin D deficiency in pregnant women of Somali origin living in Sweden. Acta Paediatrica 2011; 100: 612-4.

12. Zenkert-Andersson K, Hedeland H, Manhem P. For lite sol kan ge D-vitaminbrist. Muslimska kvinnor i sverige ar en riskgrupp [Too little exposure to sun may cause vitamin D deficiency. Muslim women in Sweden are a risk group]. Lakartidningen 1996; 93: 4153-5.

13. Zittermann A. Vitamin D in preventive medicine: are we ignoring the evidence? Br J Nutr 2003; 89: 552-72.

14. Lips P. Which circulating level of 25-hydroxyvitamin D is appropriate? J Steroid Biochem Mol Biol 2004; 89-90: 611-4.

15. Uppsalakommun. http://www.uppsala.se/sv/Kommunpolitik/ Kommunfakta/Statistik/Statistik-amnesvis/Befolkningsstatistik; 2011.

16. Livsmedelsdatabasen [database on the Internet]. http://www7. slv.se/Naringssok

17. Daryani A. http://urn.kb.se/resolve?urn=urn:nbn:se:uu:diva7103. 2006.

18. Black LJ, Seamans KM, Cashman KD, Kiely M. An updated systematic review and meta-analysis of the efficacy of vitamin $\mathrm{D}$ food fortification. J Nutr 2012; 142: 1102-8.

19. Calvo MS, Whiting SJ, Barton CN. Vitamin D fortification in the United States and Canada: current status and data needs. Am J Clin Nutr 2004; 80(6 Suppl): 1710S-6S.

20. Calvo MS, Whiting SJ, Barton CN. Vitamin D intake: a global perspective of current status. J Nutr 2005; 135: 310-6.

21. Borradale D, Kimlin M. Vitamin D in health and disease: an insight into traditional functions and new roles for the 'sunshine vitamin'. Nutr Res Rev 2009; 22: 118-36.
22. SLV. http://www.slv.se/upload/dokument/rapporter/kostunder sokningar/riksmat.pdf; 2011.

23. SLV. http://www.slv.se/upload/dokument/rapporter/mat_naring/ 2012/riksmaten_2010_2011_kortversion.pdf; 2012.

24. VRN. http://www.ravitsemusneuvottelukunta.fi/portal/se/medde landen_och_stallningstaganden; 2011.

25. Vieth R, Chan PC, MacFarlane GD. Efficacy and safety of vitamin $\mathrm{D}_{3}$ intake exceeding the lowest observed adverse effect level. Am J Clin Nutr 2001; 73: 288-94.

26. Gibson RS. Principles of nutritional assessment. Oxford: Oxford University Press; 2005.

27. Baer HJ, Blum RE, Rockett HR, Leppert J, Gardner JD, Suitor $\mathrm{CW}$, et al. Use of a food frequency questionnaire in American Indian and Caucasian pregnant women: a validation study. BMC Public Health 2005; 5: 135.

28. Taylor C, Lamparello B, Kruczek K, Anderson EJ, Hubbard J, Misra M. Validation of a food frequency questionnaire for determining calcium and vitamin $\mathrm{D}$ intake by adolescent girls with anorexia nervosa. J Am Diet Assoc 2009; 109: 479-85, 85 e1-3.

29. Snellman G. http://urn.kb.se/resolve?urn=urn:nbn:se:uu:diva159873; 2011.

30. Islam MZ, Viljakainen HT, Karkkainen MU, Saarnio E, Laitinen K, Lamberg-Allardt C. Prevalence of vitamin D deficiency and secondary hyperparathyroidism during winter in pre-menopausal Bangladeshi and Somali immigrant and ethnic Finnish women: associations with forearm bone mineral density. Br J Nutr 2012; 107: 277-83.

31. Holick MF, Binkley NC, Bischoff-Ferrari HA, Gordon CM, Hanley DA, Heaney RP, et al. Guidelines for preventing and treating vitamin D deficiency and insufficiency revisited. J Clin Endocrinol Metab 2012; 97: 1153-8.

32. Dawson-Hughes B. Racial/ethnic considerations in making recommendations for vitamin $\mathrm{D}$ for adult and elderly men and women. Am J Clin Nutr 2004; 80(6 Suppl): 1763S-6S.

33. Vimaleswaran KS, Berry DJ, Lu C, Tikkanen E, Pilz S, Hiraki LT, et al. Causal relationship between obesity and vitamin D status: bi-directional Mendelian randomization analysis of multiple cohorts. PLoS Med 2013; 10: e1001383.

34. Daryani A, Berglund L, Andersson A, Kocturk T, Becker W, Vessby B. Risk factors for coronary heart disease among immigrant women from Iran and Turkey, compared to women of Swedish ethnicity. Ethn Dis 2005; 15: 213-20.

35. Koochek A, Johansson SE, Kocturk TO, Sundquist J, Sundquist $\mathrm{K}$. Physical activity and body mass index in elderly Iranians in Sweden: a population-based study. Eur J Clin Nutr 2008; 62: 1326-32.

36. Castetbon K, Mejean C, Deschamps V, Bellin-Lestienne C, Oleko A, Darmon N, et al. Dietary behaviour and nutritional status in underprivileged people using food aid (ABENA study, 2004-2005). J Hum Nutr Diet 2011; 24: 560-71.

37. Webb AR, Engelsen O. Calculated ultraviolet exposure levels for a healthy vitamin D status. Photochem Photobiol 2006; 82: 1697-703.

38. Buzzard IM, Sievert YA. Research priorities and recommendations for dietary assessment methodology. First International Conference on Dietary Assessment Methods. Am J Clin Nutr 1994; 59: 275S-80S.

39. Hunter DJ, Sampson L, Stampfer MJ, Colditz GA, Rosner B, Willett WC. Variability in portion sizes of commonly consumed foods among a population of women in the United States. Am J Epidemiol 1988; 127: 1240-9.

40. Wirfält AE, Jeffery RW, Elmer PJ. Comparison of food frequency questionnaires: the reduced Block and Willett questionnaires differ in ranking on nutrient intakes. Am J Epidemiol 1998; 148: 1148-56. 
41. Binkley N, Krueger D, Cowgill CS, Plum L, Lake E, Hansen $\mathrm{KE}$, et al. Assay variation confounds the diagnosis of hypovitaminosis D: a call for standardization. J Clin Endocrinol Metab 2004; 89: 3152-7.

42. Ibrahim F, Parmentier C, Boudou P. Divergence in classification of 25-hydroxyvitamin D status with respect to immunoassays. Clin Chem 2007; 53: 363-4.
*Åsa Andersson

Gottsunda Primary Health Care Centre Box 25024

SE-750 25 Uppsala, Sweden

Tel: +46 I8 61।8640

Email: asa.andersson@lul.se

Appendix. Food frequency questionnaire (FFQ)

\begin{tabular}{|c|c|c|c|c|c|c|c|c|c|}
\hline How often do you eat? & Portion & Never & $\begin{array}{c}<\text { I time } \\
\text { per month }\end{array}$ & $\begin{array}{l}\text { I-2 times } \\
\text { per month }\end{array}$ & $\begin{array}{l}2-3 \text { times } \\
\text { per month }\end{array}$ & $\begin{array}{c}\text { I time } \\
\text { per week }\end{array}$ & $\begin{array}{l}2-3 \text { times } \\
\text { per week }\end{array}$ & $\begin{array}{l}\text { I time } \\
\text { per day }\end{array}$ & $\begin{array}{c}2-3 \text { times } \\
\text { per day }\end{array}$ \\
\hline Fatty fish & $125 \mathrm{~g}$ & & & & & & & & \\
\hline Eggs & $60 \mathrm{~g}$ & & & & & & & & \\
\hline Fortified milk & $2 \mathrm{dl}$ & & & & & & & & \\
\hline Milk & $2 \mathrm{dl}$ & & & & & & & & \\
\hline Fortified yoghurt & $2 \mathrm{dl}$ & & & & & & & & \\
\hline Yoghurt & $2 \mathrm{dl}$ & & & & & & & & \\
\hline Cheese & $15 \mathrm{~g}$ & & & & & & & & \\
\hline Beef & $125 \mathrm{~g}$ & & & & & & & & \\
\hline Lamb & $125 \mathrm{~g}$ & & & & & & & & \\
\hline Pork/ham & $125 \mathrm{~g}$ & & & & & & & & \\
\hline Chicken & 125 & & & & & & & & \\
\hline Margarine (for bread) & $5 \mathrm{~g}$ & & & & & & & & \\
\hline Margarine (for cooking) & $15 \mathrm{~g}$ & & & & & & & & \\
\hline Butter (cooking) & $15 \mathrm{~g}$ & & & & & & & & \\
\hline Oil & $15 \mathrm{~g}$ & & & & & & & & \\
\hline Vitamin supplements & I tablet & & & & & & & & \\
\hline
\end{tabular}

